\title{
Awareness about colon cancer in University biology student.
}

\begin{abstract}
Cancer is disease caused by abnormal growth of cells in a body of an individual. Malignancy in large intestine is termed as colon cancer. The objective of this study was to develop awareness among the university students. A questionnaire was developed comprising of 15 questions and 39students filled that awareness survey questionnaire. After survey the result shows that majority of the students were aware about colon cancer while some were unaware about the disease. Hence we concluded that there is a need to develop awareness among the people but there were few reported cases of colon cancer.
\end{abstract}

Keywords: Cancer, malignancy, colon cancer
Volume 9 Issue $3-2018$

\author{
Muhammad Imran Qadir, Hafiza Sobia Khan \\ Institute of Molecular Biology \& Biotechnology, Bahauddin \\ Zakariya University, Pakistan
}

Correspondence: Muhammad Imran Qadir, Institute of Molecular Biology \& Biotechnology, Bahauddin Zakariya University, Multan, Pakistan, Email mrimranqadir@hotmail.com

Received: April 23, 20I8 | Published: June 18, 2018

\section{Introduction}

Cancer is uncontrolled division of cells anywhere in the body. Universally, every 1 in 6persons died due to cancer, thus making it the second major cause of death. The new number of cases expected in next two decades is about $70 \%$. So the cancer become the leading cause of death worldwide. ${ }^{1}$ Colon cancer becomes the second major cause of death in females while in males it is considered as the third most common type of cancer. ${ }^{2}$ The incidence of colon cancer is much more in developed countries when compared with developing countries. ${ }^{3}$ According to an estimate the incidence of colon cancer increases 2-4times in past few years. ${ }^{4}$ However, public awareness and health care trials were insufficient not only in providing protection against colon cancer but also its detection in early stages. ${ }^{5}$ The basic purpose of this study was to determine the awareness of university student about colon cancer.

\section{Methodology}

A cross sectional study was carried among the University biology students and a questionnaire was developed (Table 1) to estimate the awareness among people about the disease. Table consists of about 15questions. 39students completely filled the questionnaire from BZU, 6 of them were males and 33 were females. The inclusion criteria for this study was students of M.Phil and exclusion criteria was not students of BS.

Table I Questionnaire to evaluate awareness about etiology of colon cancer

\begin{tabular}{rll}
\hline Colon cancer is a & Yes & No \\
\hline I. & Viral disease & \\
2. & Bacterial disease & \\
3. & Fungal disease \\
4. & Genetic disease & \\
5. & Metabolic disease &
\end{tabular}

Ever suffered from colon cancer
6. You
7. Your family
8. Your relative

\begin{tabular}{|c|c|c|}
\hline Colon cancer is a & Yes & No \\
\hline 9. Your neighbor & & \\
\hline 10. Your friend & & \\
\hline \multicolumn{3}{|l|}{ Colon cancer is transmitted by } \\
\hline $\begin{array}{l}\text { II. Contacts or blood } \\
\text { transfusion }\end{array}$ & & \\
\hline 12. From parents to offspring & & \\
\hline \multicolumn{3}{|l|}{ Colon cancer may be treated by } \\
\hline 13. Medicines & & \\
\hline 14. Surgery & & \\
\hline $\begin{array}{l}\text { 15. Do not worry, it is easily } \\
\text { curable }\end{array}$ & & \\
\hline
\end{tabular}

\section{Results and discussion}

Awareness of postgraduate students about colon cancer is given in Table 2. Out of 50questionnaires 39 were completed and we include them in this analysis. The sample comprises 6 male students and 33 female students. About one third of the students were the residents or rural areas but all were post graduate students. According to awareness survey $16.6 \%$ males and $45.5 \%$ females and $39.35 \%$ said that colon cancer is a viral disease while $33.3 \%$ males, $63.6 \%$ females and $48.45 \%$ of the total students said that it is a bacterial disease. $16.6 \%$ males, $24.2 \%$ females and $20.4 \%$ of the students considered colon cancer as a fungal disease. While $16.6 \%$ males, $42.4 \%$ females and $29.5 \%$ of the total students were not agreed that the colon cancer is genetic or metabolic disease.

Table 3 comprise questions about the incidence of colon cancer in their family and friends. None of the student, their family and relatives were ever suffered from colon cancer. $16.6 \%$ males, $0 \%$ females and $8.3 \%$ of the total student's neighbors and friends were affected from colon cancer.

Table 4 contains questions that were asked by the biology students that either colon cancer is transmitted through blood transfusion or from parents to offsprings. $33.3 \%$ males, $12.1 \%$ females and $22.7 \%$ of the total students agreed that this type of cancer transmitted with contact or blood transfusion. $16.6 \%$ males, $36.3 \%$ females and $26.45 \%$ of the total students said colon cancer transferred from parents to offsprings. 
Table 5 shows the result of questions which were asked by the students about the treatment of colon cancer. $100 \%$ males, $84.8 \%$ females and $92.2 \%$ of the total of 39 students said that it can be cured by medicines. $100 \%$ male students, $66.6 \%$ female students and $92.2 \%$ of the total students agreed that colon cancer can be treated by the surgery treatment. While $100 \%$ male students, $94 \%$ female students and $97 \%$ of the total biology students were worried about the cure of this disease.

Table 2 Awareness about etiology of colon cancer: views of university biology students

\begin{tabular}{lllllll}
\hline Questions & \multicolumn{2}{l}{ Male } & \multicolumn{3}{c}{ Female } & \multicolumn{3}{c}{ Total } \\
\cline { 2 - 7 } & Yes & No & Yes & No & Yes & No \\
\hline I.Viral disease & $16.60 \%$ & $83.30 \%$ & $45.50 \%$ & $54.50 \%$ & $39.35 \%$ & 68.9 \\
2. Bacterial disease & $33.30 \%$ & $66.60 \%$ & $63.60 \%$ & $36.30 \%$ & $48.45 \%$ & $51.55 \%$ \\
3. Fungal disease & $16.60 \%$ & $83.30 \%$ & $24.20 \%$ & $75.80 \%$ & $20.40 \%$ & $79.60 \%$ \\
4. Genetic disease & $16.60 \%$ & $83.30 \%$ & $42.40 \%$ & $57.60 \%$ & $29.50 \%$ & $70.50 \%$ \\
5. Metabolic disease & $16.60 \%$ & $83.30 \%$ & $42.40 \%$ & $57.60 \%$ & $29.50 \%$ & $70.50 \%$ \\
\hline
\end{tabular}

Table 3 Awareness about etiology of colon cancer: views of university biology students

\begin{tabular}{clllllll}
\hline \multirow{2}{*}{ Questions } & \multicolumn{2}{c}{ Male } & \multicolumn{2}{c}{ Female } & \multicolumn{2}{c}{ Total } \\
\cline { 2 - 7 } & Yes & No & Yes & No & Yes & No \\
\hline \multicolumn{2}{c}{ Ever suffered from colon cancer } & & & & & & \\
I. & You & $0.0 \%$ & $100 \%$ & $0.0 \%$ & $100 \%$ & $0.0 \%$ & $100 \%$ \\
2. & Your family & $0.0 \%$ & $100 \%$ & $0.0 \%$ & $100 \%$ & $0.0 \%$ & $100 \%$ \\
3. & Your relative & $0.0 \%$ & $100 \%$ & $0.0 \%$ & $100 \%$ & $0.0 \%$ & $100 \%$ \\
4. & Your neighbor & $16.6 \%$ & $83.3 \%$ & $0.0 \%$ & $100 \%$ & $8.3 \%$ & $91.7 \%$ \\
5. & Your friend & $16.6 \%$ & $83.3 \%$ & $3.0 \%$ & $97 \%$ & $9.8 \%$ & $90.2 \%$ \\
\hline
\end{tabular}

Table 4 Awareness about etiology of colon cancer: views of university biology students

\begin{tabular}{cllllll}
\hline \multirow{2}{*}{ Questions } & \multicolumn{2}{c}{ Male } & & Female & \multicolumn{2}{c}{ Total } \\
\cline { 2 - 7 } & Yes & No & Yes & No & Yes & No \\
\hline Colon cancer is transmitted by & & & & & & \\
I. Contacts or blood transfusion & $33.3 \%$ & $66.6 \%$ & $12.1 \%$ & $87.9 \%$ & $22.7 \%$ & $77.3 \%$ \\
2. From parents to offspring & $16.6 \%$ & $83.4 \%$ & $36.3 \%$ & $63.7 \%$ & $26.45 \%$ & $73.55 \%$ \\
\hline
\end{tabular}

Table 5 Awareness about etiology of colon cancer: views of university biology students

\begin{tabular}{lllllll}
\hline Questions & Male & \multicolumn{2}{c}{ Female } & & \multicolumn{2}{c}{ Total } \\
\cline { 2 - 6 } & Yes & No & Yes & No & Yes & No \\
\hline Colon cancer may be treated by & & & & & & \\
I. Medicines & $100 \%$ & $0.00 \%$ & $84.80 \%$ & $15.20 \%$ & $92.20 \%$ & $7.80 \%$ \\
$\begin{array}{l}\text { 2. Surgery } \\
\text { 3. Do not worry, it is easily curable }\end{array}$ & $100 \%$ & $0.00 \%$ & $66.60 \%$ & $33.40 \%$ & $83.30 \%$ & $16.70 \%$ \\
\hline
\end{tabular}

\section{Conclusion}

It was concluded from this study that the most of the university biology students were aware about colon cancer but some had poor level of knowledge. Only few cases of colon cancer were reported.

\section{Acknowledgements}

None.

\section{Conflict of interest}

The author declares no conflict of interest. 


\section{References}

1. Torre LA, Siegel RL, Ward EM, et al. Global cancer incidence and mortality rates and trends-an update. Cancer Epidemiol Biomarkers Prev. 2016;25(1):16-27.

2. Lozano R, Naghavi M, Foreman K, et al. Global and regional mortality from 235 causes of death for 20 age groups in 1990 and 2010: a systematic analysis for the global burden of disease study 2010. lancet. 2012;380(9859):2095-2128.
3. Merika E, Saif M, Katz A, et al. Colon cancer vaccines: an update. In vivo. 2010;24(5):607-628.

4. Ng SC, Wong SH. Colorectal cancer screening in Asia. British medical bulletin. 2013;105:29-42.

5. Sung JJ, Lau JY, Goh K, et al. Increasing incidence of colorectal cancer in Asia: implications for screening. The lancet oncology. 2005;6(11):871876. 